\title{
Seasonal variation of different groups of zooplankton of a wetland in relation to some abiotic factors
}

\author{
Subhendu Bikash Patra \\ Assistant Professor in Zoology, \\ Brahmananda Keshab Chandra College, Kolkata, India \\ Correspondence E-mail : subhendubp@gmail.com
}

\begin{abstract}
The zooplankton community of the wetland was represented by Protozoa, Rotifera, Cladocera and Copepoda. The Protozoan population includes ciliates and flagellates and the maximum and minimum abundance were 223 and 2 ind./lit respectively. Rotifers, the largest group were represented by a minimum of 9 ind./lit and a maximum of 1425 ind./lit. Copepods, the second largest group, comprised a minimum of 1 ind./lit and a maximum of 708 ind./lit. The other group Cladocerans was found to be in lower profile which showed no definite pattern of their seasonal variation. In this wetland water temperature (WT) varied from $19.75^{\circ} \mathrm{C}$ to $34^{\circ} \mathrm{C}$, transparency (TRN) from 31.3 to 82.5 $\mathrm{cm}$, pH from 6.5 to 8.4 , dissolved oxygen (DO) ranged from 1.3 to $10.6 \mathrm{mg} /$ lit, total alkalinity (TA) from 62 to $76 \mathrm{mg} / \mathrm{lit}$, free $\mathrm{CO}_{2}$ from 5 to $30 \mathrm{mg} /$ lit and biological oxygen demand (BOD) from 1.2 to 10.2 $\mathrm{mg} / \mathrm{lit}$. Although seasonal variation of zooplankton community is largely governed by abiotic factors, but $\mathrm{pH}$ exerted considerable influence.
\end{abstract}

Keywords: Zooplankton, Seasonal variation, Wetland, Abiotic factors.

\section{Introduction}

It is well known that wetlands are the most productive ecosystems where in various physicochemical parameters of water play a vital role in influencing the life cycle of flora and fauna present in the ecosystem. Zooplankton occupies an important position in the food chain and referred to as primary consumer and plays a key role in the transfer of both energy and nutrients to the higher trophic levels. Zooplankton of Indian inland water bodies is mainly comprises of five groups i.e Protozoa, Rotifera, Cladocera, Copepoda and Ostracoda. Among the above mentioned groups Protozoa, Rotifera, Cladocera and Copepoda are the major group take part in the formation of total Zooplankton population. Protozoa generally form a minor position in the zooplankton population.
The living organisms and their nonliving environment are inseparably linked and they interact with one another continuously. It is therefore obvious that various physicochemical factors largely regulate the entire dynamics as well as homeostasis of an ecosystem. According to Hutchinson (1941) all the physical, chemical and biological processes have an interrelationship both temporally and specially. Probably Prasad (1916) was the first to study the limnological characters of fresh water pond in India. Subsequently, several workers studied water bodies from limnological view point (Banik, 1995, Michael and Sharma, 1998, Biswas and Konar, 2000, Singh et al., 2001, Banik. 2002, Sunkad. and Patil. 2004, Kumar and Tripathi, 2004, Aswathi and Tiwari, 2004). A 
satisfactory understanding of the ecological process in an aquatic system requires a thorough knowledge not only of the organisms but also of the environmental factors. The present paper portrays the role of abiotic factors on the seasonal variation of different groups of zooplankton.

\section{Materials and Methods}

The chosen wetland is a rain fed one and situated by the side of Nazrul Mancha at Golpark, Kolkata, West Bengal, India (Lat $22^{\circ} 31^{\prime} \mathrm{N}$ and Long 88⒉'E). The surface area of this wetland is about 0.4 ha and the average depth is 3 meter. Half of the wetland is covered with macro vegetation like Ipomea sp, Nelumbo sp, Azolla sp, Lemna sp etc. Neither fish culture nor any other domestic use has been noticed in this wetland. Surface water samples and zooplankton were collected weekly for one year, between 9am and $10 \mathrm{am}$. The data are represented as monthly mean. For the physicochemical analysis of water, standard methods of APHA (1995) were followed. The zooplankton was collected with a plankton net made up of bolting silk no. 25 and their quantification was done according to Welch (1948).
During the entire study period WT varied from $19.75^{\circ} \mathrm{C}$ to $34^{\circ} \mathrm{C}$ and showed its maxima in May (Table1).On the other hand, TRN ranged from 31.3 to $82.5 \mathrm{~cm}$ and showed its highest value in January(Table1). The $\mathrm{pH}$ ranged from slightly acidic (6.5) to alkaline (8.43) with high value in March (Table1). DO content varied from 1.3 to $10.6 \mathrm{mg} / \mathrm{lit}$ and showed its maximum value in March. (Table1). TA ranged from 62 to $76 \mathrm{mg} /$ lit with high values in August (Table1). BOD varied from 2.00 to $6.67 \mathrm{mg} / \mathrm{lit}$ and its maximum value was in September (Table1).

In this wetland total zooplankton showed three peaks during study. The highest peak (1823 ind./lit.) was in April and other two small peaks were in July (181 ind./lit.) and November (282 ind./lit.) (Table 2). In this study Zooplankton exhibits a positive correlation with $\mathrm{pH}(\mathrm{p}<0.01)$ (Table 3).

Protozoan population occurred in the wetland without showing any precise trend of oscillation. During the study highest value was noted in April. The total number of Protozoan was at its peak during April (223 ind./lit.) and the other small peak in September (18ind./lit.) (Table 2). In this wetland protozoan has shown significant and positive correlation with DO $(p<0.01), p H(p<0.01)$, transparency $(p<0.01)$ (Table 3).

\section{Results}

Table: 1. Monthly variations of physicochemical parameters (mg/lit).

\begin{tabular}{|c|c|c|c|c|c|c|c|}
\hline Month & WT & TRN & $\mathrm{pH}$ & $\mathrm{DO}$ & $\mathrm{TA}$ & $\mathrm{CO}_{2}$ & $\mathrm{BOD}$ \\
\hline Jan & 19.75 & 82.50 & 6.93 & 3.60 & 69.00 & 9.00 & 5.24 \\
\hline Feb & 23.25 & 74.00 & 7.60 & 10.20 & 69.00 & 8.00 & 4.60 \\
\hline Mar & 30.50 & 63.25 & 8.43 & 10.60 & 71.00 & 5.00 & 3.80 \\
\hline Apr & 29.00 & 53.50 & 8.13 & 8.60 & 66.00 & 16.80 & 3.40 \\
\hline May & 34.00 & 40.50 & 7.80 & 7.40 & 66.00 & 5.80 & 3.20 \\
\hline Jun & 33.00 & 38.30 & 7.35 & 8.20 & 60.00 & 8.00 & 3.40 \\
\hline July & 30.50 & 34.00 & 7.08 & 6.20 & 69.00 & 8.50 & 2.94 \\
\hline Aug & 30.00 & 31.30 & 6.50 & 2.40 & 76.00 & 12.00 & 3.33 \\
\hline Sept & 29.50 & 37.00 & 6.63 & 1.30 & 68.00 & 15.00 & 6.67 \\
\hline Oct & 28.00 & 45.60 & 6.65 & 2.00 & 62.00 & 18.00 & 4.67 \\
\hline Nov & 26.00 & 52.30 & 6.69 & 2.80 & 66.00 & 18.00 & 2.00 \\
\hline Dec & 23.00 & 61.40 & 6.75 & 2.60 & 69.00 & 30.00 & 2.00 \\
\hline
\end{tabular}

In the present investigation Rotifers contributed the largest group and showed three peaks, one in Summer (April1425ind./lit.) and the other two in Monsoon (August-90ind./lit.) and Post monsoon (October-61ind./lit) (Table 2). From the simple correlation analysis it is found that rotifers shows positive correlation with $\mathrm{pH} \quad(\mathrm{p}<0.01)$ (Table 3).

Total copepods showed wide fluctuation throughout the study and their abundance is marked by many sharp long peaks and 
troughs. During study dominance of this group was recorded in summer and winter season. During study this group showed significant and positive correlation with $\mathrm{pH}(\mathrm{p}<0.05)(T a b-3)$, but inverse correlation with transparency though not significant.
Cladocera, the another zooplankton group were in lower profile during study and as such no definite pattern of their variation was observed. Highest abundance during study was noticed in late winter. During study it showed positive correlation with $\mathrm{pH}$ though not significant.

Table 2. Monthly numerical abundance of different groups of zooplankton (ind./lit).

\begin{tabular}{|c|c|c|c|c|c|}
\hline Month & Protozoa & Rotifera & Copepoda & Cladocera & Zooplankton \\
\hline Jan & 40 & 97 & 77 & 02 & 216 \\
\hline Feb & 68 & 24 & 272 & 95 & 459 \\
\hline Mar & 124 & 419 & 708 & 00 & 1251 \\
\hline Apr & 223 & 1425 & 165 & 10 & 1823 \\
\hline May & 21 & 109 & 103 & 02 & 235 \\
\hline Jun & 02 & 16 & 28 & 02 & 48 \\
\hline July & 05 & 65 & 103 & 08 & 181 \\
\hline Aug & 03 & 90 & 53 & 02 & 148 \\
\hline Sept & 18 & 22 & 34 & 02 & 66 \\
\hline Oct & 06 & 61 & 01 & 00 & 282 \\
\hline Nov & 09 & 14 & 256 & 03 & 214 \\
\hline Dec & 15 & 09 & 183 & 07 & $\mathbf{5 0 0 3}$ \\
\hline Total & $\mathbf{5 3 4}$ & $\mathbf{2 3 5 1}$ & $\mathbf{1 9 8 3}$ & $\mathbf{1 3 3}$ & \\
\hline
\end{tabular}

In this present observation Rotifera comprises $46 \%$, Copepoda comprises $39 \%$, Protozoa contribute $11 \%$ and Cladocera only $3 \%$ to the formation of total Zooplankton community. (Fig.1)

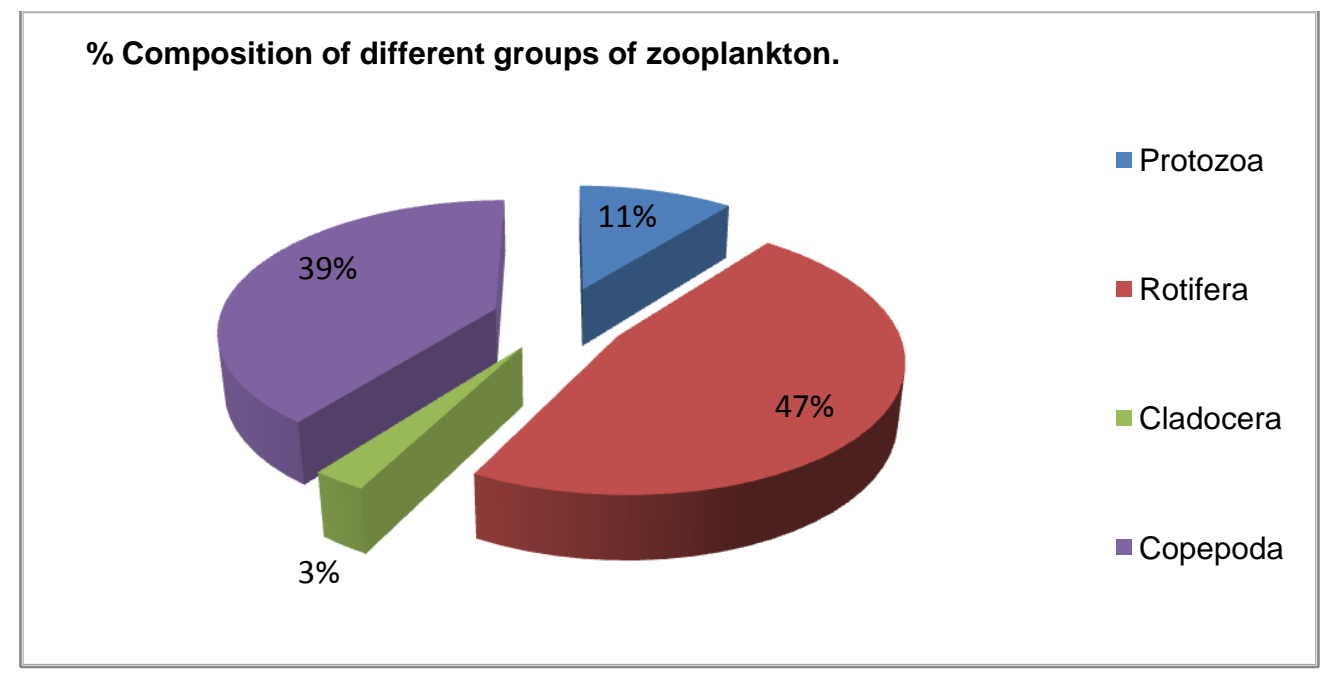

Fig.1. \% Composition of different groups of zooplankton. 
Table 3. Simple correlation co-efficient ( $r$ ) between physicochemical Parameters and different Groups of zooplankton.

\begin{tabular}{|c|c|c|c|c|c|}
\hline Parameter & Protozoa & Rotifera & Cladocera & Copepoda & Zooplankton \\
\hline WT & -0.245 & 0.196 & -0.166 & 0.056 & 0.102 \\
\hline TRN & $0.472^{*}$ & 0.009 & 0.303 & 0.306 & 0.221 \\
\hline $\mathrm{pH}$ & $0.524^{* *}$ & $0.448^{*}$ & 0.193 & $0.459^{*}$ & $0.561^{* *}$ \\
\hline $\mathrm{TA}$ & 0.124 & -0.081 & -0.122 & -0.063 & -0.067 \\
\hline $\mathrm{DO}$ & $0.616^{* *}$ & 0.188 & 0.322 & 0.359 & 0.376 \\
\hline $\mathrm{CO}_{2}$ & -0.1525 & 0.0874 & -0.1145 & -0.1329 & -0.0298 \\
\hline $\mathrm{BOD}$ & -0.009 & -0.201 & -0.205 & -0.323 & -0.277 \\
\hline
\end{tabular}

${ }^{*} \mathrm{p}<0.05 ;{ }^{* *} \mathrm{p}<0.01$

\section{Discussion}

The present paper has been envisaged to elucidate and interpret the variations as well as the interaction of the physico- chemical parameters of water. This is especially important from the ecological view points because physicochemical parameters as ecological indices give a picture of the water quality, a resultant of the geo-physicochemical and biological nexus and its further implications on the overall limnological status of the water body and also the water chemistry have been found to be better predictor of planktonic biomass and productivity than other biotic data (Paloheimo and Fulthrop, 1987).

Under the regime of good climatic condition of West Bengal, India the water temperature in the present study was found always below $35^{\circ} \mathrm{c}$ and above $19^{\circ} \mathrm{c}$ (Tab-1). Therefore, such a seasonal variation in water temperature very well coincides with the optimum temperature range favourable for healthy growth of most aquatic organisms. Transparency is an effective indicator of the measurement of productivity (Chapman, 1992). In the present study less transparency was noticed in summer which may be attributed to the increase in the phytoplankton population. During the study positive and significant correlation between $\mathrm{pH}$ and transparency is in agreement with the views of Schofiels(1972) and Schindler (1980) who opined acidification increases transparency of natural water.

According to Goldman and Horne, 1983, Chapman, 1992, pH of water provides an index of general chemical environmental condition and productivity status of an aquatic ecosystem. In the present study decrease in
$\mathrm{pH}$ in monsoon and post monsoon may be attributing to resulting in formation of carbonic acid $\left(\mathrm{H}_{2} \mathrm{CO}_{3}\right)$ which after dissociating into $\mathrm{H}^{+}$ and $\mathrm{HCO}_{3}{ }^{-}$ions displays acidic characteristics (Khan and Chowdhury, 1994). During study the higher values of $\mathrm{pH}$ were recorded mainly in summer months. This summer maxima of $\mathrm{pH}$ possibly result from increased photosynthesis utilizing free $\mathrm{CO}_{2}$ present in water (Goldman, 1972). According to Chapman, 1992, natural water mostly has $\mathrm{pH}$ from 6 to 8.5. In the present study also $\mathrm{pH}$ ranges from 6.5 to 8.43 i.e from slightly acidic to alkaline (Tab-1). In the present study $\mathrm{pH}$ shows inverse and significant correlation with $\mathrm{CO}_{2}$. It was also observed by Golterman et. al. (1978). The removal of $\mathrm{CO}_{2}$ during photodynthesis is always coupled with the production of oxygen and increase of $\mathrm{pH}$ has explained the positive correlation between $\mathrm{pH}$ and dissolved oxygen during study (Table 3 ). In this wetland $\mathrm{pH}$ has a positive correlation with alkalinity which corroborates the findings of Wetzel (1983).During the study Dissolved oxygen (DO) varies from 1.3 to $10.6 \mathrm{mg} / \mathrm{lit}$. Self purification of any wetland is a direct function of the dissolved oxygen concentration in its water. The dissolved oxygen content of water is the result of both photosynthetic as well as decomposition of organic matter and wind action (Ellis et al. (1946). In the present studied wetland aquatic macrophytes perhaps play a significant role. According to Kemp and Murray (1986) oxygen release from submerged aquatic macrophytes influence the oxygen concentration of water. 
Free oxygen experienced wide fluctuations during study and no definite trend has been observed (Table 1). In the present studied wetland it is high perhaps due to presence of macrovegetation. Increase of free $\mathrm{CO}_{2}$ content in the natural waters take place following respiratory activities which get reduced due to photosynthesis (Sreenivasan, 1967). Higher levels of free $\mathrm{CO}_{2}$ in post monsoon month may be attributed to its influx through rain water in the form of carbonic acid (Mansoori et al. 1995) and lower level during summer (Table 1) might be due to high photosynthetic activity using free $\mathrm{CO}_{2}$ (Yousuf et al.,1986). In the winter months higher value of free $\mathrm{CO}_{2}$ is probably due to low photosynthetic activity and higher rate of Zooplankton productivity (Jackson, 1970). The oxygen and carbon di oxide are reciprocal to each other in the ecosystem. The oxygen content is closely linked with carbon di oxide cycle and higher values of free $\mathrm{CO}_{2}$ generally coincided with minimum DO content as also mentioned by Sarkar and Krishnamoorti (1979). In the present study also follow the above contention.

Alkalinity used as tool for the measurement of productivity of water bodies. In the present course of study maximum value was noted in winter and post winter months and minimum value was obtained in monsoon. The minimum value in monsoon months may be due to neutralization of carbonic acid.

According to young (1984) Biological Oxygen Demand (BOD) gives an indication of bacterial population and availability of organic biodegradable substances. During study higher BOD value was noticed in post monsoon period. This is perhaps due to higher load of organic matter by surface run off during monsoon and higher bacterial activity.

Lake water sparkling in sunlight hides a miniscule waterscape is closer to a slum than a paradise. It contains millions of organisms present in every litre of water. Organisms that passively drift maintained in suspension by water current or float or swim comprise the plankton which also include the free swimming Zooplankton. In the present investigation four groups of Zooplankton (i.e Protozoa, rotifera, cladocera, copepoda) have been identified.
This four groups of zooplankton also been reported by Pushpendra and Madhyastha (1994) in fresh water ponds. In the present study altogether 57 species of Rotifera, 13 of Cladocera, 5 of Copepoda were found. From the present observation it appears that the fresh water body of Indian subcontinent have more species probably due to congenial habitat and effectiveness of limiting factor which regulate the occurrence and abundance of planktonic forms. It is relevant to mention that Nasar (1977), George(1966) also recorded similar type of species composition during their study.

In the present study the abundance of total Zooplankton in the wetland showed many variations in different season. In the present study higher abundance was observed in summer and a small peak in winter was also noticed, which corroborates with the study of George (1966). Zooplankton is considered as one of the most important linkage in aquatic food chain and shows continuous seasonal variation which is influenced by different physicochemical factors. From the present study, based on seasonal observation, it is apparent that the Zooplankton community as a whole has a tendency to show their peaks in different season of the year. In the present study the influence of several physicochemical factors on the occurrence and abundance of total population was also noticed. The simple correlation coefficient $(r)$ values between the abundance of total zooplankton and the physicochemical parameters show that the total zooplankton exhibited significant and positive correlation with $\mathrm{pH}(\mathrm{p}<0.01)$.

It is generally believed that temperature is one of the most important factors in ecosystem in controlling both the total quality and species composition of zooplankton but it cannot be the only important variable.

Protozoan population occurred in the wetland without showing any precise trend of oscillation. During the study highest value was noted in April. The total number of Protozoan was at its peak during April (223 ind./lit.) and the other small peak in September (18ind./lit.). According to Michael (1969) it may be stated that the nature and the amount of available food is the controlling factor in the distribution 
of fresh water Protozoan. In this wetland protozoan has shown significant and positive correlation with DO $(p<0.01), \mathrm{pH} \quad(p<0.01)$, transparency $(p<0.01)(T a b-3)$. It is well known that $\mathrm{pH}$ and oxygen content of water are mainly regulated by photosynthesis and respiration in fresh water system. Pennak (1978) is of the opinion that the great majority of protozoa have optimum conditions in slightly acidic to alkaline waters ( $\mathrm{pH}$ 6.5-8). During the present investigation similar type of water quality was observed showing significant and positive correlation between $\mathrm{pH}$ and protozoa.

The rotifers are almost universally present in fresh water habitat and constitute an important component of zoobiota. Like many other, in the present investigation Rotifers contributed the largest group and showed three peaks, one in Summer (April-1425ind./lit.) and the other two in Monsoon (August-90ind./lit.) and Post monsoon (October-61ind./lit) (Tab-2). So the fluctuation pattern of the total community was influence mainly by this group. It may be mentioned that according to Reid and Wood (1976) rotifers never follow any predictable pattern in fresh water impoundment. From the simple correlation analysis it is found that rotifers shows positive correlation with $\mathrm{pH}$ $(p<0.05)$. This type of observation was also observed by Venkhede and Kulkarni(1984).

Total copepods showed wide fluctuation throughout the study and their abundance is marked by many sharp long peaks and troughs. During study dominance of this group

\section{References}

APHA, (1995). Slandered methods for the examination of water and waste water, $19^{\text {th }}$ edn. Washington. D.C

Aswathi, U., and Tiwari, S. (2004). Seasonal trends in abiotic factors of a lentic habitat (Govindgarh lake) Rewa, M.P, India. Eco. Env. \& Cons. 10(2), 65-170.

Bandyopadhyay, B.K. (1985). Hydrobiology of some Brackish and Freshwater Ecosystem of West Bengal,India.Ph.D. Thesis, University of Calcutta.

Banik, S. (1995). Zooplankton abundance in a freshwater fish farming pond in West was recorded in summer and winter season. During study this group showed significant and positive correlation with $\mathrm{pH} \quad(\mathrm{p}<0.05)$ but inverse correlation with transparency though not significant.

Cladocera, the another zooplankton group were in lower profile during study and as such no definite pattern of their variation was observed. Highest abundance during study was noticed in late winter, which is also supported by the study of Prasadam (1977). During study it showed positive correlation with $\mathrm{pH}$ though not significant.

\section{Conclusion}

Generally in natural waters, an approximate biological equilibrium exists, although abundance of zooplankton varies from season to season. The growth of zooplankton is directly or indirectly influenced by the seasonal variation in the complexes of various abiotic factors. The annual changes in the community of zooplankton depend on the succession of its component species. Some plankton species increase slowly and more or less uniformly reaching to the maximum while others showed an almost starting burst of development rising from minimal population to a numerical dominance over the whole plankton within a very short period of time. Such variations are mostly related to abiotic factors.

Bengal,India. Ph.D Thesis, University of Calcutta.

Banik, S., (2002). Two new species of Genus Collotheca Harring 1913 (Rotifera: Monogononta) from freshwaters of Tripura, India. Journal of Bombay Natural History Society. 99(2), 262-266.

Biswas, B .K and Konar, S.K. (2000). Influences of Nunia Nullah(Canal) discharge on plankton abundances and diversity. In: The River Damodar at Narankuri (Raniganj) in West Bengal. Indian J. Environ. \& Ecoplan.3, 209-217. 
Chapman, D. (1992). Water quality assessments. A guide to the use of biota, sediments and water in environmental monitoring. Chapman and Hall.

Ellis, M.N. Westfall,B.A., and Ellis, M.C. (1946). Determination of water quality. Fish and Wildlife Service U.S. Dept. Interior Res. 9, 122.

George, M.G. (1966). Comparative plankton ecology of five fish tank in Delhi, India. Hydrobiologia, 27(1-4), 81-108.

Goldman, C.R. (1972). The role of minor nutrients in limiting the productivity of aquatic ecosystem. 21-38. In: Netrients and Eutrophication. Am. Soc. Limnol. Occeangr. Spec.Symp.1.

Goldman, C.R and Horne,A.J. (1983). Limnology. McGraw-Hill International Book Company, New York.

Golterman, H.L., Clymo,R.S. and Ohnstad, M.A.M. (1978). Methods for Physical and Chemical Analysis of Freshwater (2 ${ }^{\text {nd }} E d$.). Blackwell Scientific Publ. Oxford.

Hutchinson,G.E. (1941). Limnological studies in Connecticut. IV. The mechanism of intermediary metabolismin stratified lakes. Ecol. Monogr., 11, 21-60.

Jakson,H.W. (1970). Oxygen relationship in polluted waters. In Taftsan, R.A. (Ed.) Water pollution Ecology, Eng. Centre, U.S. Dept. Of Health, Education and Welfare; Occasional paper No. 2.

Khan, M. A. G and Chowdhury, S. H. (1994). Physical abd Chemical limnology of lake Kaptai. Bangladesh. Trop. Ecol. 35(1), 35-51.

Kemp, W.M and Murray, L. (1986). Oxygen release from roots of the submerged macrifhytes, Patamogeton pertoliatus L. Regulating factors and ecological implications. Aquatic Bot., 26, 271-283.

Kumar, A., \& Tripathi, S., (2004). Zooplankton diversity in relation to aquaculture in some ponds of Durg-Bhillai city, Chhattisgarh state. Nature, Environment and Pollution Technology, 3(2), 175-178.

Mansoori, H.A, Lavania, R.K, and Tiwari, R.K. (1995). Hydrobiological study of Lakshmital lake Jhansi with special reference to plankton productivity. Flora and Fauna, 1(1), 39-42.

Michael, R.G. (1969). Seasonal trends in physicochemical factors and plankton of a freshwater fish pond and their role in fish culture. Hysrobiol. 33, 144-160.

Michael, R.G \& Sharma, B. K. (1998). Fauna of India, Zoological Survey of India, Kolkata.262.

Nasar, S.A.K. (1977). Investigation on the seasonal periodicity of zooplankton in a freshwater pond in Bhagalpur, India. Acta. Hydrochim. Hydrobiol.5, 577-584.

Prasad, B. (1916). The seasonal conditions governing the pond life in Punjab. J. Asiat. Soc. Beng.12, 142-145.

Pennak, R.W. (1955). Comparative limnology of eight Mountain lakes. IUNIV. Clo. Stud. Sr. Biol.OT2:75.

Pennak, R.W. (1978). Freshwater Invertebrates of the United States. John Wiley and Sons. Inc. New York.

Palaoheimo, J.E. \& Fulthorpe, R.R .(1987). Factors influencing plankton community structure and production in freshwater lakes. Can. Aquat. Sct., 44(3), 650-657.

Prasadam, R.D. (1977). Observations on Zooplankton population of some freshwater impoundments in Karnataka. Proc. Symp. Warmwat. Zooplankton. M.I.O. Goa, 214-225.

Pushpendra \& Madhyastha , M.N. 1994. Seasonal variation and diversity of zooplankton in a small pond near Mangalore. J. Ecobiol., 6(3), 197-200.

Reid, G.K \& Wood, R.D. (1976). Ecol. Of inland waters and Estuaries. D. Van. Nostrand Co., N. Y.485.

Sarkar, R. \& Krishnamoorthi, K.P. (1979). Diurnal variation studies of zooplankton in sewage fertilized fish ponds, Nagpur. Ind. J. Env. HIth. 20(4), 366-389.

Schofield, C.O, (1972). The ecological significance of air pollution induced changes in water quality of dilute lake districts in the north cost. Trams. N.E.Fish will-life conf. 98-112.

Schindler, D.W. (1980). Experimental acidification of a Whole lake, a test of the 
oligotrophication hypothesis.P.370-374. In: D. Drablos and A. Tollan [Ed.]. Ecological impact acid precipitation. Proc. Conf. Sandefjord. Norway. 11-14, 383.

Singh, A.K, Singh, P.K. \& Srivastav, S.P. 2001. Studies on abiotic factors of Sher Shah Tomb Tank, Sasaram (Bihar) with special references to the Physical factors. Proceedings of the $88^{\text {th }}$ sci. Cong.N.Delhi.

Sreenivasan, A. (1967). Application and primary production studies in fish culture. Proc. F.A.O. World Symp. Warm Water pond fish culture, Rome, Itali, (18-21) (1966),101-113.

Sunkad, B.N., \& Patil, H.S., (2004). Water quality assessment of fort lake of Belgaum (Karnataka) with special reference to zooplankton. J. Environ. Biol. 25(1), 99-102.

Venkhede, G.N., \& Kulkarni, K.M. (1984). Physicochemical condition and plankton populations of two lakes near Amaravati, Maharastra. Environment and Ecology, 2 (2), 131-133.

Whitman, R., Nevers, B.M., Goodrich, L.M., Murphy, C.P., and Davis. M.B., (2004). Characterization of lake Michigan coastal lakes using zooplankton assemblages. Ecological indicators. Elsevier publications. 4, 277-286.
Welch, P.S. (1948). Limnological methods. McGraw. Hill Book Co. Inc.Blakiston Div. Philadelphia.

Welch, P.S. (1952). Limnology. McGraw Hill Book Co. New York. 538.

Wetzel, R.G. (1983). Limnology. $2^{\text {nd }}$ Eds. Saunders Coll.Publ. 767

Young, J.C. (1984). Waste strength and water pollution parameter. Water Analysis: 1-38. Academic Press Inc.

Yusuf, A.R, Balkhi, M.H \& Quadri, M.Y. (1986). Limnological features of a forest lake of Kashmir. J. Zool. Soc. India. 38(1\&2), 20-42.

\section{Abbreviation used:}

WT- Water Temperature; TRN- Transparency; DO- Dissolved Oxygen; TA-Total Alkalinity; BOD- Biological Oxygen Demand; $\mathrm{CO}_{2}$ Carbon di oxide 